\title{
Explicating failure among nascent entrepreneurs in West Sumatra: The nexus of psycho-economic factors and opportunistic behavior
}

\author{
Hafiz Rahman $^{1}$ (D) Eri Besra², Nurhayati ${ }^{3}$
}

\begin{abstract}
This paper investigates and discusses individuals' internal circumstances as factors that may cause entrepreneurial failure, which consists of psycho-economic phenomenon and opportunistic behavior of individuals. The study is a quantitative study, and it operates relational analysis that relates existing arguments regarding psycho-economic factors to entrepreneurial failure. The study further adds and analyses the construct of opportunistic behavior as another possible factor that may cause entrepreneurial failure. The sample of the study is 1541 young entrepreneurs in West Sumatra Province, Indonesia, who have experienced failures in their previous businesses. The analysis was undertaken by using multiple and partial regression analysis in which the statistical protocol was operated. It is found that psycho-economic factors, together with opportunistic behavior of individuals in a lesser to a greater degree, have caused entrepreneurial failure to the context of the study. The study also implies and argues that opportunistic behavior may not only be viewed as a source of entrepreneurial success, as it also contributes to entrepreneurial failure. This finding clearly demonstrates the originality and value of this study since it argues that opportunistic behavior can also be viewed as a factor - apart from the other existing psycho-economic factors (deterministic, voluntaristic, and emotive) - that can cause entrepreneurial failure. The study further suggests that strengthening entrepreneurial personality, characteristics and psychological aspects should be a focus for the Indonesian government in promoting and developing young-nascent entrepreneurs.
\end{abstract}

Keywords: deterministic-voluntaristic-emotive factors, entrepreneurial failure, psycho-economic factors, opportunistic behavior

1 Hafiz Rahman, Ph.D, Department of Management, Faculty of Economics, Universitas Andalas, Kampus Universitas Andalas, Limau Manis, Padang 25163 West Sumatra, Indonesia, e-mail: hafizrahman@eb.unand.ac.id (ORCID ID: 0000-0003-0873-7456), corresponding author.

2 Eri Besra, Ph.D., Department of Management, Faculty of Economics, Universitas Andalas, Kampus Universitas Andalas, Limau Manis, Padang 25163 West Sumatra, Indonesia, e-mail: eribesra@eb.unand.ac.id

3 Nurhayati, Department of Business Administration, Politeknik Negeri Padang, Limau Manis, Padang 25163 West Sumatra, Indonesia, e-mail: nurhayati@pnp.ac.id 


\section{INTRODUCTION}

The most important entrepreneurial learning that can be absorbed by entrepreneurs supposes to be sourced from their experience regarding failures. Almost all entrepreneurs have experienced failure when they undertook their business. In a study about the anatomy of entrepreneurs, Wadhwa, Holly, Aggarwal, and Salkever (2009) came out with the finding that successful entrepreneurs have experienced, on average, two to three failures in new ventures that they established before they reached success. This situation, and the condition of failure, has triggered entrepreneurs to become tougher, more resilient and, crucially, more able to learn from failures. Therefore, analyzing failure as a part of an entrepreneurial journey is necessary, since entrepreneurs cannot avoid it to achieve success. The existence of failure as an event in an entrepreneurial journey - followed by mental and learning processes and an experiential process - has raised a particular concept in entrepreneurship, which is introduced as the concept of serial entrepreneurship.

Lafontaine and Shaw (2014) mentioned that the serial entrepreneurship could be understood as an entrepreneurial process which happens to an entrepreneur in achieving success in new ventures after he/she has experienced failures, in which the following element exists: [a] the learning process from the failure, [b] the process of change in entrepreneurial behavior after the failure, and [c] the experience of managing the business. There are no uniform arguments and opinions from scholars to state the number of venture failures that occurred and were experienced by entrepreneurs before he/she reached entrepreneurial success. It is believed that the number of venture failures before achieving entrepreneurial success is situationally, conditionally, and contextually related to an entrepreneur as a person. This means that most entrepreneurs will experience entrepreneurial failure - and the number of failures varies among them. However, one common argument raised and approved by the scholars is that entrepreneurial success is very seldom achieved in the first single venture creation/establishment.

Studies and research to reveal the determinants of entrepreneurial success factors have clearly identified that entrepreneurial success is influenced by: [a] the internal and external environments of the entrepreneur, [b] the psychological condition and situation of the entrepreneur, and [c] the sociological situation of the entrepreneur (Rahman \& Day, 2014). A recent study from Bratnika-Myśliwiec, Wronka-Pośpiech, and Ingram (2019) mentioned that socioemotional wealth (SEW) would be beneficial for the creation of competitive advantage of the family business. Therefore it should be regarded as a strategic antecedent for firm performance. Each factor has 
its own specific determinants, in which opportunism is considered as one major psychological determinant that can lead to entrepreneurial success (see, for example, the studies from Chang, Liu, \& Chiang, 2014; Herath, 2014; Wasdani \& Matthew, 2014).

An interesting question, therefore, is: what would be the other sensible psycho-economic construct apart from the existing deterministic, voluntaristic, and emotive factors that may cause entrepreneurial failure? Further, is there any determinant in entrepreneurial success factors that can play intersection roles with the determinant of entrepreneurial failure? Based on that consideration, part of this study tries to examine and discuss the possibility of opportunistic behavior being identified and introduced as a possible determinant that may not only be viewed as the determinant in entrepreneurial success but also influences entrepreneurial failure. As previously described by Andrunik and Svetlakov (2013), the existence of opportunistic behavior will always create conflicts and bargain situations inside individuals, and they tend to choose a decision which they prefer emotionally and makes them feel comfortable. This tendency would reasonably put individuals in a decision dilemma, whether they will follow their emotional feeling or their rationality. In many cases, the proclivity to choose to follow an emotional feeling is rather more prominent than to use rationality.

In the context of business and management, the opportunistic behavior of individuals has also been proven to bring negative consequences. Unsal and Taylor (2011), for example, have empirically demonstrated that the opportunistic behavior of individuals negates the negative practices in project collaboration and will result in inefficiency. Previously and similarly, Yaqub (2009) mentioned that collective benefits would not be obtained by members of an organization if there are self-interest-based actions undertaken by certain individual members of that respective organization. Self-interest from individuals will result in a moral hazard that also leads to other negative actions such as shirking and free-riding, which have an impact on an organization. Meanwhile, in the context of the firm, Cordes, Richerson, McElreath, and Strimling (2010) found that the existence of high opportunism-related behavior amongst individuals within the firm will cost the growth of the firm. Firms will remain small in size, and social learning processes within the firm will remain stagnant.

Taking nascent entrepreneurs in West Sumatra - Indonesia as the unit of analysis and context of the study, it tries to reveal the psycho-economic phenomenon experienced by nascent entrepreneurs that have led to entrepreneurial failure. In detail, this study reveals entrepreneurial failure within nascent entrepreneurs in West Sumatra, which was caused as the result of psycho-economic phenomenon together with opportunistic behavior. 
Culturally, the West Sumatran people are characterized as a society that has high uncertainty avoidance, as found by Hofstede (2018) and Mangundjaya (2010). This cultural dimension has made the West Sumatran prefer and tend to choose and to maintain a stable situation in their life. In their mindset, this stability can only be achieved when they have regular income to finance their daily needs. In the turbulent and unstable situation of the Indonesian economy, the opportunity to get a regular income can only be achieved if people have a formal job where they get a monthly salary and get a pension in the future. Related to young-nascent entrepreneurs, unfortunately, there is no guarantee that every newly started micro-small-medium business can survive in a more challenging business situation in Indonesia. Therefore, there is a phenomenon of young-nascent entrepreneurs in the context of the study, choosing to have a regular job - even though they have actually started a business.

This study was quantitatively undertaken with 1541 nascent entrepreneurs in West Sumatra, who have experienced entrepreneurial failure. Our preliminary investigation through a pilot study found that the number of entrepreneurial failures experienced by the West Sumatran nascent entrepreneurs averagely reaches three to four times until they can settle the business and achieve success. This situation is a challenging one - as people usually undertake the necessary steps and efforts to reduce the failure rate. Therefore, this study is interesting and valuable as it tries to reveal the entrepreneurial failure phenomenon experienced by nascent entrepreneurs, which can be used as a reliable source and foundation to state and support government policies regarding nascent entrepreneurs.

\section{LITERATURE REVIEW}

In general, entrepreneurial failure can be understood as the cessation of an entrepreneurial process undertaken by entrepreneurs as a result of failures that occurred during the preparation, implementation, and management of the venture. One main possible sign of this failure can be seen in the inability of the entrepreneur to manage financial matters, which has further resulted in the cessation of business operation, and worse - bankruptcy. However, even though the inability to manage financial matters is closely linked to bankruptcy, it cannot be viewed as the only reason for entrepreneurial failure. Instead of the inability to manage financial matters of the venture, entrepreneurial failure is mainly viewed as a result of the combination and interaction between the psychological and economic factors of an entrepreneur. It is perceived that psychological factors of individuals will lead them to decide and further, to undertake error actions - which will 
further result in entrepreneurial failure. As Smida and Khelil (2010) point out, entrepreneurial failure is a psycho-economic phenomenon which will lead entrepreneurs to undertake error actions to allocate resources and will result in further consequences, in terms of the psychological situation in the form of disappointment. However, entrepreneurial failure can be concluded as the situation in which the psycho-economic phenomenon relates to:

- the individual situation and condition (in particular behavior and personality);

- the organization as a business entity where an entrepreneur undertakes entrepreneurial process;

- the social environment which is directly and/or indirectly relates to individuals;

- the entrepreneurial process happening to individuals.

However, these four factors individually cannot influence entrepreneurial failure as it does not have sufficient power to lead to failure. There should be a combination and an interaction between these factors and elements which will impact the failure of the businesses run by entrepreneurs.

Knowledge and observation regarding entrepreneurial failure are considered important, as one of the main concerns in entrepreneurship is to minimize the failure rate of new businesses. Even though entrepreneurs are described as individuals who can tackle risks (including business risks), we view the information and knowledge regarding failures as a guidance that can also be used by nascent entrepreneurs in preparing their business. The information and knowledge regarding failures can also be used to reduce the rate of the serial entrepreneurship process that happened to entrepreneurs. In addition, failures will also be a learning event, and experience from the post-mortem assessment to analyze the reasons for entrepreneurial failure. One of these post-mortem assessments is in the form of a cognitive structural analysis that can be used by entrepreneurs to analyze the type of failure and re-motivate themselves to be back in business, getting experiences from cases, finding a new ability to face and tackle failures and, the most important, to determine the transformation process of failures into opportunities. Entrepreneurs can use their failure experiences to reflect on themselves and take further benefits for the operation of their business from the future. The positive impact of failure may also be categorized as a eustress for entrepreneurs, who can take reflective practices from these failures (Tikkamäki, Heikkilä \& Ainasoja, 2016).

Study and research regarding new venture failures are usually emphasized by the analysis of the following topics: [a] what new ventures fail and why? (Artinger \& Powell, 2015; van Gelder, Fries, Frese, \& Goutbeek, 2007), and [b] what are the consequences that need to be borne by entrepreneurs as the 
result of their failures (Jenkins, Wiklund, \& Brundin, 2014; Singh, Corner \& Pavlovich, 2015; Yamakawa, \& Cardon, 2015; Ucbasaran, Westhead, Wright, \& Flores, 2010)? Contextually, most of the studies and research that have been completed analyzed that the consequences of business failure belong to the entrepreneur - which means that the analysis has mainly been done on the business as an entity. Considering this, research contexts were mostly centered on the question 'why can be a business fail?' Wennberg, Wiklund, DeTienne, and Cardon (2010) concluded that business mainly fails because of the following reasons: [a] low business performance, [b] the problem of resources, and [c] unachievable positive goals and growth of the business. On a broader scale, Hammer (2014), and Wennberg and DeTienne (2014), further identified the existence of three conditions that can lead to a failure in business, which are: [a] business environment, [b] the business itself - mainly inappropriate resources and competence, and [c] the entrepreneur as an individual/person - mainly less commitment from entrepreneurs in managing the business.

If we objectively observe business failure, in particular new ventures, failure is closely related to the analysis of those who are operating the business. This means that the entrepreneur, as a person, is considered as an individual who has a prominent role in determining whether a business can succeed or fail. Therefore, the unit analysis of the research cannot always be focused on the business as an entity. That is why we put the emphasis on our focus and analysis merely to the entrepreneur as an individual. According to Smida and Khelil (2010), the concept of business and organizational failure can be viewed from the entrepreneur as an individual, and it is sourced from: [a] deterministic factors, and [b] voluntaristic factors. A deterministic factor is defined as the failure of a new venture which is sourced from the entrepreneur's environment, as its existence cannot be minimally controlled by the entrepreneur. As Cardon, Stevens, and Porter (2011) mentioned, the deterministic factor of business failure comes from the entrepreneur's environment, which cannot be avoided by entrepreneurs in their business operation. In reverse, Mellahi and Wilkinson (2010) mentioned that voluntaristic factors related to business failure are sourced from errors made by entrepreneurs in making decisions and conducting actions. It can be inferred from Mellahi and Wilkinson (2010) that the deterministic factor is not the only factor that results in business failure - it can also be voluntaristic factors.

Cardon et al. (2011) further stated that business failure is not a result/ consequence of an uncontrollable situation and condition by the entrepreneur, such as the environment factor. One possible source of the business failure instead comes from a stigma that is embedded inside entrepreneurs which makes them try as hard as they can to avoid it - but unfortunately, they end 
up making false decisions and wrong actions, and as a result of these, their business fails (Singh et al., 2015). Khelil (2016) further mentioned that apart from deterministic and voluntaristic factors, as did Cardon et al. (2011), there is also an emotive factor inside entrepreneurs, which is a decisive factor in entrepreneurial failure. An emotive factor, as meant by Khelil (2016), is described as a factor that can show interaction and combination between business performances achieved by entrepreneurs (in terms of failure) and the disappointment of that unachieved business performance. In relation to this, the finding of Hammer (2014) also showed us the indication of a goalsetting bias in entrepreneurs as a major source of business failure. Goal setting bias happens because of the unlatch situation between expectation and real business performance experienced by entrepreneurs. This emotive factor (Khelil, 2016) is an interaction and combination between deterministic and voluntaristic factors in entrepreneurial failure. Therefore, failure is not only sourced from an uncontrollable/difficult-to-control environment, but it is also sourced from errors in decision making and wrong-doing actions done by the entrepreneur in managing the business.

In previous studies, Khelil (2012) mentioned that failure in a new venture mostly happened because of the following patterns and types that are embedded in an entrepreneur as an individual: [a] gambler - ones who would like to start a business without resources and without any clear orientation, [b] supported at arm's length - ones who have limited resources, [c] bankrupt - ones who have limited competencies, [d] megalomaniac - ones who have too much self-confidence, and [e] dissatisfied with the Lord - ones who do not fully rely on God's will. We can further categorize these reasons into two categories: [a] individual personality as a source of failure (consists of gambler, megalomaniac, dissatisfied with the Lord), and [b] the environmental situation as a source of failure [consists of supported at arm's length and bankrupt). Meanwhile, Hammer and Khelil (2014) strengthened the analysis about entrepreneurial failure by saying that it was based on the consideration of input, process, and output in the new venture creation process at individual and enterprise levels. They further draw this in Figure 1 below, which shows the model of entrepreneurial failure that would be experienced by entrepreneurs. 


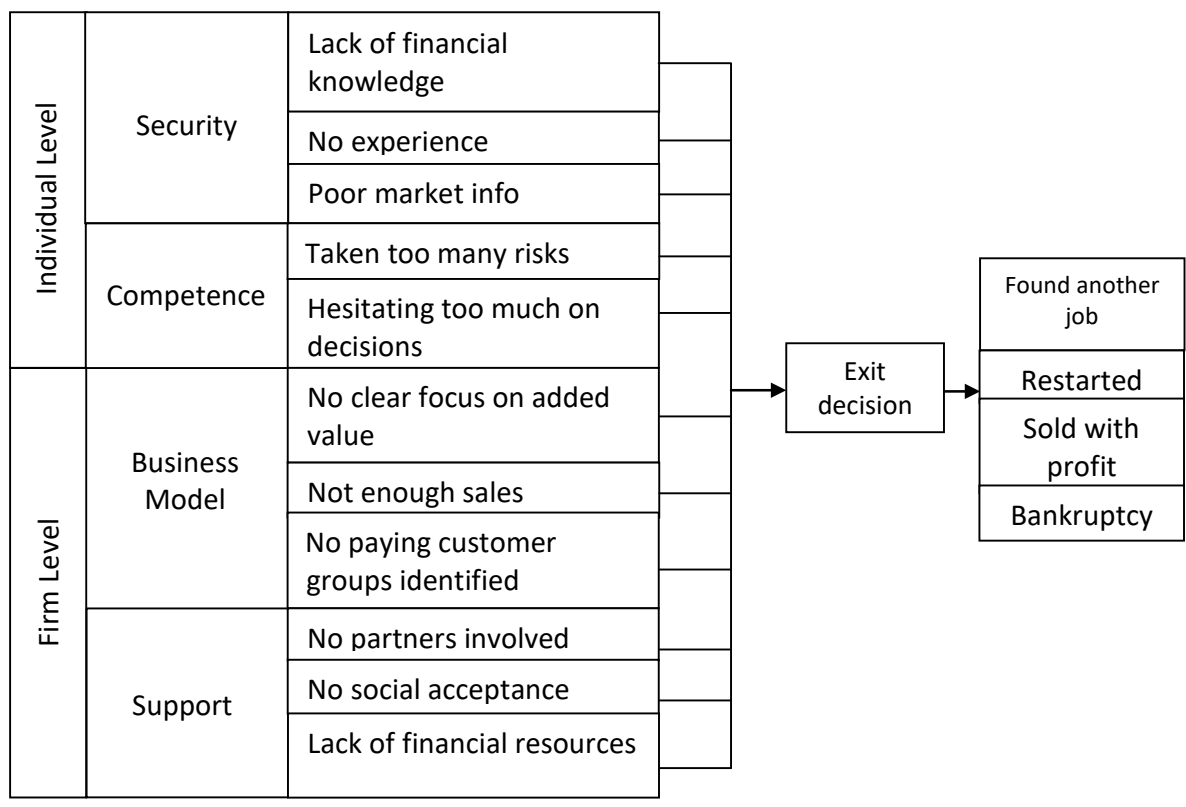

Figure 1. The Model of Entrepreneurial Failure Source: Hammer and Khelil (2014).

The model infers that entrepreneurial failure in the form of an exit decision from the business is drawn as the result of: [a] individual level which has competency and security as its dimensions, and [b] firm level which has support and business model as its dimensions. The existence of both factors will lead entrepreneurs to a decision to cease their business - and, therefore, the business fails. A further impact of this exit decision can lead entrepreneurs to try to find other jobs, restarting a new venture, or selling their business with the hope that they will get some profits or worst, bankruptcy.

Concept and studies regarding opportunism mostly related to the opportunistic behavior of individuals, and it mentioned that this opportunistic behavior is a hidden will of an individual which can have a negative impact on the business and it is shown by efforts to achieve that hidden will (Cordes et al., 2010). Andrunik and Svetlakov (2013) and Cordes et al. (2010) have further revealed that the existence of opportunistic behavior is closely related to the transaction cost concept and will create conflicts and bargain situations in which individuals need to choose the one most appropriate choice from many alternative decisions. Both of those concepts are clearly related to the topic of this paper and study - and they demonstrate an indication that an entrepreneur will prefer a situation that brings more benefits to him/her personally. This situation can be in terms of an alternative to secure a better 
job compared with a career in entrepreneurship, or the desire to start other new businesses but in the condition that the earlier business is still unstable or immature. This situation will put entrepreneurs in a conflict or a bargaining position that requires them to make their own decision - securing and entering a job, or starting another new venture, or maintaining the earlier venture to reach its maturity. Sometimes the decision is a good and powerful decision, but it can also be a poor decision, which will lead them to the failure of the earlier venture. We can see here that entrepreneurs can be trapped in an individual level psychological situation (Hammer \& Khelil, 2014), where they are asked to secure their future life on the possibility of a future career that they do not possess at the moment.

In the study of impacts and consequences of entrepreneurial failure, Mantere, Aula, Schildt, and Vaara (2013) mentioned that entrepreneurial failure is a social construction where the process of individual psychology in terms of [a] the existence of emotional processes and [b] cognitive process to justify every action, exists. In entrepreneurship, an increasing cognitive load within individuals is viewed to bring high intrinsic motivation (Liang \& Liang, 2015), which will be used as a psychological factor to start a business. We can conclude from this opinion that entrepreneurial failure may bring psychological impacts to the failed entrepreneurs - and as a result, they are trying to do their best to maintain their self-esteem and to avoid losing their own business. Psychological impacts can also be seen in efforts to reduce, and moreover, to eliminate the stigma that arises from failure (Singh et al. 2015). An interesting phenomenon regarding the existence of stigma lies in the fact that it can also be a source of the next failure. As Singh et al. (2015) say, the fear of failure and efforts to stay away from the stigma of failure have, contradictively, resulted in negative situations for an entrepreneur - as he/she will probably make a poor decision and take a wrong action in the business. As a result, this will make entrepreneurs sink into failure (again). Therefore, the stigma of failure can be seen as a psychological reason and impact on why an entrepreneur fails in the business.

Following the studies and opinions from Arasti (2011), Fatoki (2014), and Mellahi and Wilkinson (2010) regarding entrepreneurial failure, there is a clear indication that deterministic factor can be viewed as one of the major reasons that cause entrepreneurial failure. We use this as our foundation to state the initial hypothesis in this study. Combining it with the opinion from Khelil (2010) and Hammer and Khelil (2014), we further formulate our first hypothesis as the following:

H1: A deterministic factor in terms of [a] the existence of support to entrepreneurs, [b] social situation and social environment, [c] competition 
in the industry, and [d] the high operation cost of the business has brought positive and significant influence to the creation of entrepreneurial failure within nascent entrepreneurs in West Sumatra.

In a study about the economic situation and its influence on the success and failure factor of a business, Devece, Peris-Ortiz, and Rueda-Armengot (2016) mentioned that the individual characteristics of an entrepreneur in a specific economic situation would influence the success or failure of a business start-up. Based on this study and opinion, as well as Khelil (2010), we further state the second hypothesis in our study.

H2: A voluntaristic factor in the form of [a] individual competencies, [b] individual orientation and [c] entrepreneurial behavior towards customers will bring a positive and significant influence to the creation of entrepreneurial failure by nascent entrepreneurs in West Sumatra.

In relation to the emotive factor, Khelil (2016) and, previously, Mellahi and Sminia (2009) argued that this factor has a close relationship with the motivation, commitment, and aspiration of an entrepreneur when they undertake their business. We further posit that the emotive factor, as a psychological construct inside an entrepreneur as an individual, will determine the success or failure in his/her business. From Khelil (2016), we view that this psychological condition will create pressure, within the nascent entrepreneur and his/her social environment, to get a job soon. We consider this situation as a necessity-based situation where individuals have limited employment opportunities, failed to get a job, and failed during an application/interview for a job. As this is the primary motivation, there will be a significant impact on the creation of failure in business. We further formulate our third hypothesis as below.

H3. An emotive factor in the form of [a] psychological pressure to get income and [b] the indication of a necessity-based motive in entrepreneurship has brought positive and significant influence to entrepreneurial failure experienced by nascent entrepreneurs in West Sumatra.

In the context of developing countries (such as Indonesia), which still have very limited employment opportunities, the existence of its cultural dimension (Hofstede, 2018) and the nature of its cultural values (Mangundjaya, 2010) have been perceived as a burden for entrepreneurship. In relation to this, the study viewed that there is a tendency of pattern and opportunistic behavior that exists within nascent entrepreneurs in Indonesia. 
As Yakovleva, Grigoryeva and Grigoryeva (2016) mentioned, opportunistic behavior can be seen as behavior manipulations of individuals and the nature of exogenous opportunistic manifestations as a society and economic phenomenon. This opportunistic behavior will lead nascent entrepreneurs to leave their business once they get a job offer or an opportunity to get a job (either in a public or private institution). In the context of corporate management, Andrunik and Svetlakov (2013) mentioned that the moral hazard has become an acute problem in corporate management, due to the results of the transformation of social relations, the changes to the status of company employees and managers, the development of stock markets, and the increasing complexity of products. It is viewed that opportunistic behavior is the mode of action for the economic entity, not limited by moral considerations, accompanied by the acts of deception, contradicting the interests of other agents, and characterized by a tendency to implement only proper interests.

In addition to that overview, this study also considers aggressivity inside individuals as a construct of opportunistic behavior that belongs to nascent entrepreneurs. Aggressivity will lead nascent entrepreneurs to neglect their initial business since they have an uncontrollable passion for creating and establishing other businesses. In relation to the consideration regarding aggressivity, this study added one concept regarding opportunistic behavior as an additional construct that can cause entrepreneurial failure. Therefore, this study formulates its fourth hypothesis in the following statement.

H4. Opportunistic behavior which is related to an opportunity to get a job, get higher income, future security, and aggressivity in starting businesses, will positively and significantly influence entrepreneurial failure within nascent entrepreneurs in West Sumatra.

H5. Furthermore, this study also formulates the next hypothesis by saying that [a] deterministic, [b] emotive, [c] voluntaristic, and [d] opportunistic behavior will simultaneously influence entrepreneurial failure experienced by nascent entrepreneurs in West Sumatra.

Based on these five hypotheses, this study has further developed its framework and research method. 


\section{RESEARCH METHOD}

The study is an explanatory study, and it operates a quantitative methodology as its leading research approach. Causal analysis is used to investigate the simultaneous as well as partial relationship and the influence of every psychoeconomic factor and opportunistic behavior as variables of the research to the entrepreneurial failure. A small portion of qualitative analysis to the open answers from the respondents was also used to support the quantitative part of the study. Cross-sectional cohort data and information were mainly collected by using a questionnaire as the research instrument.

The population of failed nascent entrepreneurs in West Sumatra is unknown since there is no recorded formal data regarding its number. Therefore, we used a simple random method as the sampling technique, and the questionnaire was distributed to the failed nascent entrepreneurs in eighteen regencies and municipalities in West Sumatra. The study firstly intended to collect data from 100 respondents in each regency and municipality in West Sumatra Province. Therefore, as many as 1800 questionnaires were prepared and distributed to the prospective respondents of the study. 1541 of them $(85.61 \%)$ were completely filled in by the respondents and can be analyzed. This number was further used as the sample size of the study. The study considers its samples as gender neutral, which means that gender is not considered as the sampling criteria, and it does not consider certain business branches as the business background of the samples.

The operation of variables in the research uses the following guidelines.

Specifically, and as in Table 1, opportunistic behavior is measured based on the conceptual foundation that there will be transactional circumstances that occur to individuals regarding the choice of their future life. In this study, it is reflected with the possibility of a person: [a] to choose a better job rather than entrepreneurship, [b] to choose to secure a job in a longer period, and $[c]$ the possibility of a person to follow his/her desire to immediately establish other new ventures but in the condition that the earlier business is still unstable or immature. Both these possibilities are then connected to the possibility of failure in the earlier business that an entrepreneur has. For this purpose, findings and results of the study were analyzed by using multiple regression analysis and supported by the use of SPSS as the statistical tool. Design of the research framework in this study uses Figure 2 below. 
Table 1. Operation of variables

\begin{tabular}{|c|c|c|c|c|}
\hline No & Variables & Dimension & Indicators & Measurement \\
\hline 1 & $\begin{array}{l}\text { Entrepreneurial } \\
\text { failure }\end{array}$ & $\begin{array}{l}\text { a. Failure to allocate } \\
\text { resources } \\
\text { b. Failure in } \\
\text { decision-making } \\
\text { c. Failure in actions }\end{array}$ & $\begin{array}{l}\text { a. Ineffectivity and } \\
\text { inefficiency in allocating } \\
\text { resources } \\
\text { b. Decision-making is not } \\
\text { based on data, } \\
\text { information, and facts } \\
\text { c. Actions do not fit with } \\
\text { what is supposed to be } \\
\text { done }\end{array}$ & $\begin{array}{l}\text { Likert scale 1- } 5 \\
9 \text { questions }\end{array}$ \\
\hline 2 & $\begin{array}{l}\text { Deterministic } \\
\text { factors }\end{array}$ & $\begin{array}{l}\text { a. The availability of } \\
\text { support } \\
\text { b. Social } \\
\text { environment of } \\
\text { entrepreneurs } \\
\text { c. Competition } \\
\text { d. High operational } \\
\text { cost of the } \\
\text { business }\end{array}$ & $\begin{array}{l}\text { a. The existence of social } \\
\text { support from the nearest } \\
\text { social environment } \\
\text { b. Response of social } \\
\text { environment to the } \\
\text { choice of becoming an } \\
\text { entrepreneur } \\
\text { c. Degree of competition } \\
\text { Level of operational cost }\end{array}$ & $\begin{array}{l}\text { Likert scale 1-5 } \\
11 \text { questions }\end{array}$ \\
\hline 3 & $\begin{array}{l}\text { Voluntaristic } \\
\text { factors }\end{array}$ & $\begin{array}{l}\text { a. Competencies } \\
\text { b. Individual } \\
\text { orientation } \\
\text { c. Behavior related } \\
\text { to customers }\end{array}$ & $\begin{array}{l}\text { a. Level of knowledge, } \\
\text { skills, motivation and } \\
\text { personal characteristics } \\
\text { b. Personal orientation of } \\
\text { the entrepreneurs } \\
\text { c. Response to customers } \\
\text { complaints and needs }\end{array}$ & $\begin{array}{l}\text { Likert scale } 1-5 \\
14 \text { questions }\end{array}$ \\
\hline 4 & Emotive factors & $\begin{array}{l}\text { a. Psychological } \\
\text { pressures to get } \\
\text { income } \\
\text { b. Necessity motives }\end{array}$ & $\begin{array}{l}\text { a. Level of psychological } \\
\text { pressure to get income } \\
\text { b. Necessity-based motives } \\
\text { in entrepreneurship }\end{array}$ & $\begin{array}{l}\text { Likert scale 1-5 } \\
8 \text { questions }\end{array}$ \\
\hline 5 & $\begin{array}{l}\text { Opportunistic } \\
\text { behavior }\end{array}$ & $\begin{array}{l}\text { a. The possibility to } \\
\text { get a better job } \\
\text { b. Job security in } \\
\text { a longer period } \\
\text { c. Desire and much } \\
\text { passion to start } \\
\text { other businesses }\end{array}$ & $\begin{array}{l}\text { a. Level of income that } \\
\text { would be received } \\
\text { continuously } \\
\text { b. High level of social status } \\
\text { c. Opportunity to get } \\
\text { a better career } \\
\text { d. Level of intention to start } \\
\text { other businesses }\end{array}$ & $\begin{array}{l}\text { Likert scale 1-5 } \\
8 \text { questions }\end{array}$ \\
\hline
\end{tabular}

Cordes et al. (2010), and Yakovleva et al. (2016). 


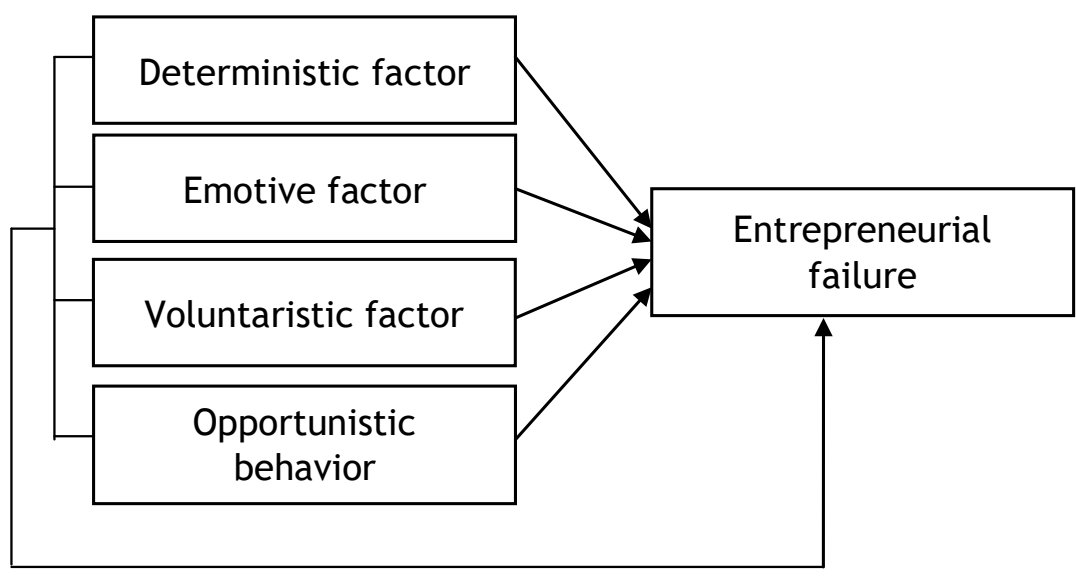

Figure 2. Research Framework

Source: conception of the authors, adopted from Mellahi and Wilkinson (2010), Khelil (2010), and Hammer and Khelil (2014).

Based on the research framework developed in Figure 2, we further arrange it in the following statistical equation that will be used as the multiple regression model of the study.

$Y_{\text {ef }}=a+b_{1} X_{v}+b_{2} X_{d}+b_{3} X_{e}+b_{4} X_{o}+e$

where:

$\mathrm{Y}_{\mathrm{ef}} \quad=$ entrepreneurial failure

$\mathrm{X}_{\mathrm{v}} \quad=$ voluntaristic factors

$\mathrm{X}_{\mathrm{d}} \quad=$ deterministic factors

$\mathrm{X}_{\mathrm{e}} \quad=$ emotive factors

$\mathrm{X}_{\mathrm{o}} \quad=$ opportunistic behaviour

$\mathrm{e} \quad=$ error

a

= constant

The statistical model which is developed for this study is used as the basis to measure the simultaneous influence of: [a] voluntaristic, [b] deterministic, [c] emotive, and [d] opportunistic behavior to entrepreneurial failure. As the concept of entrepreneurial failure and nature of the data analyzed in the study, we use the F-test statistic to test this model. To measure the influence of each independent variable on entrepreneurial failure as the dependent variable, we operate a t-test statistic. 


\section{RESULTS AND FINDINGS}

Our first task in this study is to investigate and further to reveal profiles of our sample, which is divided into two categories: [a] personal profile and [b] business profile, which belongs to the sample. Our major intention is to prove that descriptively, our samples fit with the sampling criteria previously stated in the methodology part of this paper. The personal profile of our sample is shown integrated into Table 2 below.

Table 2. Sample profile of the study (personal profile)

\begin{tabular}{llrrr}
\hline Category & Characteristic & $\begin{array}{r}\text { Number of } \\
\text { sample }\end{array}$ & $\begin{array}{r}\text { Percentage } \\
\text { (\%) }\end{array}$ & $\begin{array}{r}\text { Valid } \\
\text { percent }\end{array}$ \\
\hline Gender & Male Female & 840 & 54.51 & 54.51 \\
& & 701 & 45.49 & 100.00 \\
\hline Level of & Elementary \& & & & \\
Education & Junior High School & 147 & 9.60 & 9.60 \\
& Senior High School & 724 & 47.00 & 56.60 \\
& Undergraduate & 669 & 43.40 & 100.00 \\
\hline Age (years) & $18-20$ & 62 & 4.23 & 4.23 \\
& $21-25$ & 716 & 46.46 & 50.69 \\
& $26-30$ & 763 & 49.51 & 100.00 \\
\hline Age when & $18-20$ & 491 & 31.86 & 31.86 \\
first starting & $21-23$ & 726 & 47.11 & 78.97 \\
a business & $24-26$ & 252 & 16.35 & 95.32 \\
(years) & $27-30$ & 72 & 4.68 & 100.00 \\
\hline
\end{tabular}

Source: survey data, processed.

Despite showing a gender profile of our sample in Table 2, we consider our sample as gender neutral. This means that we do not consider and do not concentrate our study on the gender perspective of our samples as we believe that both (either male or female) may experience the same business failure. We are more interested in discussing our sample profiles from the perspectives of age, level of education, and the age when they are first starting a business because we think those profiles are more related to the exposition and the elaboration on why entrepreneurs fail in their business.

We can see from Table 2 that the majority of our sample is the male respondent and is dominated by individuals who are in the age of 26-30 years, have attended the higher education institution and were mostly in the age of 21-23 years when they first started the business. The demographic characteristics of our samples are viewed to bring influence 
to entrepreneurial failure experienced by them, considering their ability to absorb new knowledge and skills in business. As the justification for using the demographic characteristics in our study, we consider the opinion of Talas et al. (2013), who previously argued that gender, age, education and the type of school previously attended by individuals are the demographic factors that can influence entrepreneurship. Meanwhile, the profile of the business belonging to our sample is shown in Table 3 below.

Table 3. Sample profile of the study (business profile)

\begin{tabular}{llrrr}
\hline Category & Characteristic & $\begin{array}{r}\text { Number of } \\
\text { sample }\end{array}$ & $\begin{array}{r}\text { Percentage } \\
\text { (\%) }\end{array}$ & $\begin{array}{r}\text { Valid } \\
\text { Percent }\end{array}$ \\
\hline & 2nd & 990 & 64.24 & 64.24 \\
Current business & 3rd & 426 & 27.64 & 91.89 \\
is the.. & th & 84 & 5.45 & 97.34 \\
& 5th & 13 & 0.84 & 98.18 \\
& $>5$ th & 28 & 1.82 & 100.00 \\
\hline \multirow{2}{*}{ Number } & 1 & 1101 & 71.45 & 71.45 \\
experiencing failure & 2 & 353 & 22.91 & 94.35 \\
& 3 & 57 & 3.70 & 98.05 \\
& 5 & 16 & 1.04 & 99.09 \\
& $>5$ & 1 & 0.06 & 99.16 \\
& 5 & 13 & 0.84 & 100.00 \\
\hline
\end{tabular}

Source: survey data, processed.

Table 3 suggests that our samples had a business that previously experienced failures. The majority of our samples' current businesses are second businesses, which means that the previous one had failed. Our sample also revealed that they mostly (1101 samples) experienced business failure once. If we look at Table 2 closely, there is an indication of the process of serial entrepreneurship that happened to our sample. Our samples still have courage in the business (either in the same business as the previous one or starting a completely new one with a different business branch). As Lafontaine and Shaw (2014) previously argued, serial entrepreneurship is the journey of an entrepreneur experiencing failures in order to achieve success, in which the processes of [a] learning from the failure, [b] change in entrepreneurial behavior after the failure, and [c] experience in managing the business, are taking place during the failure. Processes and experiences during business operations, which result in failures, will bring a further impact on the creation of entrepreneurial resilience. Entrepreneurs can take benefits from this process by improving their personal capacity to make realistic business plans, have self-confidence and a positive self-image, possess communication skills, 
and have the capacity to manage strong feelings and impulses (American Psychological Association [APA], 2010). Those will be further used as the main sources of entrepreneurial learning. As Jenkins et al. (2014) and Wadhwa et al. (2009) argued, learning from failure is an essential characteristic of entrepreneurs - and once an entrepreneur learns from the failures they experienced then there are more possibilities to rebuild the business and to achieve success in the business.

Our second task in the study is to measure whether the questions in our research instrument (questionnaire) are valid and reliable. For this purpose, we use an r-table with a value of 0.1308 as the basis for the validity analysis. Our validity measurement shows that the value of Corrected ItemTotal Correlation for deterministic, voluntaristic, emotive, and opportunism factors are bigger than the value of the r-table (0.1308). We then conclude that questions in our research instrument are valid. The measurement of reliability in our study uses the reliability statistics table - in which the rule says that variables are reliable if they have a value of Cronbach's alpha of more than 0.7. The measurement of reliability statistics from our research instrument shows the following results.

Table 4. Reliability statistics of the variables

\begin{tabular}{ll}
\hline Variables & Cronbach's Alpha \\
\hline Entrepreneurial failure [EF] & 0.843 \\
Deterministic factors [DEF] & 0.783 \\
Voluntaristic factors [VEF] & 0.828 \\
Emotive factors [EEF] & 0.823 \\
Opportunistic behaviour [OEF] & 0.766 \\
Source: survey data, processed. &
\end{tabular}

As we can see from Table 4, the reliability measurement shows that Cronbach's alpha for all variables of entrepreneurial failures [EF], deterministic [DEF], voluntaristic [VEF], emotive [EEF] and opportunistic behavior [OEF] factors are bigger than 0.7 - which means that all points in our questionnaire are reliable. We then measured the simultaneous influence of DEF, VEF, EEF, and OEF to entrepreneurial failure. Using multiple regression analysis, the finding shows the following result. 
Table 5. The result of multiple regression analysis ( $f$-test) to measure the simultaneous influence of DEF, VEF, EEF, and OEF to entrepreneurial failure

\begin{tabular}{llrlll}
\hline Model & $\begin{array}{l}\text { Sum of } \\
\text { Squares }\end{array}$ & \multicolumn{1}{c}{ Df } & $\begin{array}{l}\text { Mean } \\
\text { Square }\end{array}$ & F & Sig. \\
\hline${ }^{1}$ Regression & 30720.010 & 4 & 7680.003 & 217.249 & $.000^{\mathrm{a}}$ \\
Residual & 106795.989 & 3021 & 35.351 & & \\
Total & 137515.999 & 3025 & & & \\
\hline
\end{tabular}

Note: ${ }^{1}$ Predictors: (Constant), DEF, VEF, EEF, OEF ${ }^{2}$ dependent variable: EF

Source: primary data analysis.

Itcan be seen from the result of the multiple regression analysis undertaken in this study that the value of $F$ is 217.249 with the Sig. 0.000 . As this value is less than $\alpha=5 \%$, we can summarize that the regression model of this study can be used to predict entrepreneurial failure. Our finding indicates that the four independent variables in this study, namely, deterministic [DEF], voluntaristic [VEF], emotive [EEF] and opportunistic behavior [OEF] are simultaneously and statistically significant in influencing entrepreneurial failure. This finding is further used as the statistical proof and solid basis regarding the acceptance of hypothesis $5(H 5)$ of the study which says that [a] deterministic factor, [b] emotive factor, [c] voluntaristic factor, and [d] the opportunistic behavior will simultaneously influence entrepreneurial failure experienced by nascent entrepreneurs in various regencies and municipalities West Sumatra.

The final task of the study is to measure the result of the t-test in order to get results regarding the possible relationship between each independent variable of the study, which is deterministic factor [DEF], voluntaristic factor [VEF], emotive factor [EEF] and the opportunistic behavior [OEF] to entrepreneurial failure [EF]. The t-test of the study allows us to analyze the partial relationship between each of the independent variables to the dependent variable. The result is then shown in Table 6 below.

The partial regression analysis using the t-test is used to measure the relationship between [a] EF and DEF, [b] EF and VEF, [c] EF, and EEF and [d] EF and OEF. The t-test of each relationship between dependent and independent variable shows the values 3.470 (for EF and DEF), 7.396 (for EF and VEF), 16.168 (for EF and EEF), and 9.236 (for EF and OEF). We also found that Sig. value for all relationships is between 0.000 and 0.001 . Since they are less than $\alpha=5 \%$, we can summarize that the partial regression model from each of the variables DEF, VEF, EEF, and OEF are statistically significant with entrepreneurial failure. This significance is also supported by the finding of the $p$-value for each relationship between variables of the study, which is 0.001 for EF_DEF and 0.000 for each of EF_VEF, EF_EEF, and EF_OEF. 
Table 6. The result of partial regression analysis (t-test) to measure the influence of DEF, VEF, EEF, and OEF to entrepreneurial failure

\section{Unstandardized Standardized coefficients coefficients}

\begin{tabular}{lllllll}
\hline Model & B & Std. Error Beta & \multicolumn{1}{l}{ t } & Sig. & P-Value \\
\hline (Constant) & 7.393 & 1.049 & & 7.045 & 0.000 & \\
EF_DEF & 0.068 & 0.019 & 0.062 & 3.470 & 0.001 & 0.001 \\
EF_VEF & 0.126 & 0.017 & 0.126 & 7.396 & 0.000 & 0.000 \\
EF_EEF & 0.323 & 0.020 & 0.300 & 16.168 & 0.000 & 0.000 \\
EF_OEF & 0.195 & 0.021 & 0.167 & 9.236 & 0.000 & 0.000 \\
\hline
\end{tabular}

Note: Predictors: (Constant), DEF, VEF, EEF, OEF; dependent variable: EF Source: primary data analysis.

The results of the partial regression analysis using the t-test were further used as the basis to stipulate the statistical model of the study, which is:

$Y_{e f}=7.393+0.126 X_{v}+0.068 X_{d}+0.323 X_{e}+0.195 X_{o}+e$

where:

$$
\begin{array}{ll}
\mathrm{Y}_{\mathrm{ef}} & =\text { entrepreneurial failure } \\
\mathrm{X}_{\mathrm{v}} & =\text { voluntaristic factors } \\
\mathrm{X}_{\mathrm{d}} & =\text { deterministic factors } \\
\mathrm{X}_{\mathrm{e}} & =\text { emotive factors } \\
\mathrm{X}_{\mathrm{o}} & =\text { opportunistic behaviour } \\
\mathrm{e} & =\text { error } \\
\mathrm{a} & =\text { constant }
\end{array}
$$

We further used the results of the partial regression analysis as the basis to prove that hypotheses $1,2,3$, and $4(\mathrm{H} 1, \mathrm{H} 2, \mathrm{H} 3$, and $\mathrm{H} 4)$ of this study can be accepted. Recalling the $\mathrm{H} 1, \mathrm{H} 2, \mathrm{H} 3$, and $\mathrm{H} 4$, there is a positive and significant influence between [a] deterministic factor $(H 1),[b]$ voluntaristic factor $(H 2)$, [c] emotive factor $(H 3)$, and [d] opportunistic behavior $(H 4)$ to the occurrence of entrepreneurial failure within nascent entrepreneurs in West Sumatra. 
In supporting the finding for $\mathrm{H} 1$, respondents of the study qualitatively revealed from the open answers that they experience inability and often struggle to calculate the most efficient business and operational costs of their business. A respondent directly answered the following:

"Honestly, we are not able to and don't have any idea of how to keep the costs as low as possible." (source: respondent number 792, male, 27 years old, not yet married, bachelor degree).

This expression has clearly indicated that respondents of the study have problems related to the deterministic factor that has brought an impact on entrepreneurial failure. Related to $\mathrm{H} 3$, respondents of the study expressed the following:

"...since I have graduated and gained my bachelor degree, I automatically have to fulfill all my daily needs. I feel a pressure about this, and it always haunts me when I undertake my business." (source: respondent number 1037, female, 22 years old, not yet married, bachelor degree).

"Well, it becomes more difficult and more challenging for me once I married and have my family...As you know, our culture requires us to fill the needs of our family once we have married, and it is very difficult for me because my business is still not settled yet." (source: respondent number 346, male, 28 years old, married, senior high school degree).

Both of these expressions from respondents of the study inferred that the feeling of responsibility to fulfill personal needs and the daily needs of the family have contributed to the creation of pressures inside nascent entrepreneurs, which has further resulted in entrepreneurial failure.

Meanwhile, in relation to the hypotheses $\mathrm{H} 4$ regarding opportunistic behavior, many of the respondents of the study revealed the following:

"...I think it is not a mistake to wait for a job even though I am currently doing my own business, is it? ..." (source: respondent number 784, female, 24 years old, not yet married, senior high school degree).

"Of course I will choose to have a job, rather than staying in this business" (source: respondent number 1377, male, 27 years old, not yet married, bachelor degree).

"As you know, there is no guarantee that you will succeed once you have entered into a business. It was a simple choice for me that I need to secure my own future as well as my family's. Where can I get this? Pension..." (source: respondent number 1439, female, 29 years old, married, bachelor degree). 
Opinion and expression regarding the feeling of respondents (the failed entrepreneurs) above have clearly given us an insight that choosing to have a job in order to secure the future life has been a major decision for respondents in the study. They don't care even if they have already had a business and tend to leave it once they have secured a job for their future.

As a response to the findings of the study, we specifically put our attention to the construct of opportunistic behavior (OEF) and its relationship to entrepreneurial failure. From the partial regression model above, it has a t-value of 9.236 with Sig. 0.000 - which means that the construct of opportunistic behavior is statistically significant enough to influence entrepreneurial failure. Using our understanding of this model and its relationship, we further argue that the opportunistic behavior which arises within individuals can be predicted as another factor (apart from the deterministic, voluntaristic, and emotive factors) that can cause entrepreneurial failure experienced by nascent entrepreneurs.

\section{DISCUSSION}

Our study proves that the psycho-economic phenomenon of individuals, which consists of: [a] voluntaristic factor, [b] emotive factor, and [c] deterministic factor are influencing the entrepreneurial failures experienced by West Sumatran nascent entrepreneurs. If we look at the descriptive results gathered from our sample, the most deterministic factor that causes failure is the inability of our respondents to meet the most efficient operational costs in their business. In emotive factors, most of our respondents revealed that the pressure to fulfill their personal and family needs have stressed them and have contributed to their failure in business. In the descriptive analysis of the construct of opportunistic behavior, most of our sample was found to think and view that getting into entrepreneurship is just a way to wait for a formal job - and once that opportunity comes, they will simply cease and leave their business. The main findings of the study, which are related to the psycho-economic phenomenon of individuals, empirically support and confirm the opinion of Hammer and Khelil (2014) and Smida and Khelil (2011) about organizational failure, which is sourced from those three factors (deterministic, voluntaristic and emotive). Similar to Mellahi and Wilkinson (2010) and as the main result of our finding, we also argue that the interaction and combination of the psychological and economic circumstances of individuals in terms of deterministic, voluntaristic, and emotive factors have caused and contributed to business and organizational failure. 
Further, our study also argues that proxies of [a] choosing a better job rather than entrepreneurship, [b] choosing to secure a job in a longer period, and $[c]$ the possibility of individuals to follow their desire to immediately establish other new ventures, but in the condition that the earlier business is still unstable or immature, are representing the construct of opportunistic behavior. We argue that when the opportunistic behavior of individuals is simultaneously combined with their psycho-economic circumstance as an entrepreneur, then it will cause and positively contribute to the occurrence of entrepreneurial failure experienced by them. As in the partial regression analysis, we also found that the opportunistic behaviour of individuals could partially cause entrepreneurial failure. In this essence, the correlation between the opportunistic behaviour of the respondents and entrepreneurial failure is explained as the following.

Firstly, our sample that already had a business but then had an opportunity to enter into the formal job market tends to leave his/her business and will concentrate on working in a job as an employee. Our further investigation clarifies the fact about the reason for respondents to concentrate on a job rather than on the business. It is mostly related to the motive and interest in securing their future life. If we consider the culture of Indonesian people in general, one particular cultural dimension and value of Indonesian people is the high uncertainty avoidance (Hofstede, 2018) and Mangundjaya, 2010). This culture and value have made Indonesian people prefer to choose a stable situation in their life - and in their mindset, this stability can only be achieved when they have a formal job where they can get a regular monthly salary and a pension in the future. Although the cultural perspective of Indonesian people shows this, psychologically, we can understand why our sample prefers to have a job to maintain them, rather than to stay in business. The feeling of insecurity regarding their future life is impacted by [a] the limited chances and severe competition in the job market and [b] the insecure business environment, which includes severe business competition, inconsistent government rules, less supported regulation and laws about business environments (especially those which are related to small and medium scale enterprises), as well as insecure sustainable business operation have psychologically influenced respondents to choose to have a job once the opportunity appears. This psychological circumstance has made respondents leave his/her business, and as a consequence, the attention to their business vanishes, and further, the business fails. Our finding is also relevant to the opinion of Hammer and Khelil (2014) who argued that the exit decision of entrepreneurs could be in the form of finding another job. Our empirical study has proven the mechanism as to why this occurs in the context of our study. 
This situation is also relevant to the condition of the opportunistic behavior of individuals, as previously described by Andrunik and Svetlakov (2013) and Cordes et al. (2010). They revealed that there would be a creation of conflicts and bargain situations in which individuals tend to choose one most appropriate choice from many alternative decisions. In the case of the respondents of the study, this is shown by their preference to choose a formal job rather than staying in the business that they have started. We consider and are viewing this psychological circumstance as a sign of opportunistic behavior that impacts and causes entrepreneurial failure.

Secondly, our study also found that within our sample, some have an uncontrollable passion in business that led them to be very aggressive in terms of creating new ventures. They believe that business is always about taking new opportunities only - but they forget that they also need to concentrate on the existing business that has been started earlier. This uncontrollable passion has made some respondents tend to follow their desire to immediately establish other new ventures even though the condition of the previous/earlier business is still unstable or immature. We also view this as a psychological circumstance sourced from opportunistic behavior. This circumstance leads individuals to choose their passion and desire (which could be uncontrollable) to get success quickly (i.e., by immediately starting other new ventures) rather than being patient until their initial business reaches maturity stage.

In this essence, we carefully put our attention to the construct of opportunistic behavior by considering the maturity of the initial and earlier business as an event that may or may not raise opportunistic behavior. If an entrepreneur follows his/her desire and has (uncontrollable) passion in creating new ventures in the situation where his/her earlier business has not yet reached the maturity stage, then we view this circumstance as opportunistic behavior. In contrast, if an entrepreneur creates a new venture after his/her earlier business has reached the maturity stage, we view this as a consequence to develop and improve the business scale. Entrepreneurs always want to improve their business scale, and one of the strategies is through business diversification, acquisition, or merger. Therefore, in this particular case and circumstance, we would not say that entrepreneurs have opportunistic behavior.

Following the findings of our study and a deeper elaboration, we argue that the construct of opportunistic behavior should not only be considered as a psychological factor that can influence entrepreneurial and firm success. Unlike most of the scholars, who argued that opportunistic behavior is considered as an entrepreneurial success factor, we rather believe that this construct may have two positions: [1] as a factor for entrepreneurial success and [2], at the same time, as a factor in entrepreneurial failure. 
The findings of our empirical study regarding the opportunistic behavior of individuals, which are proxied by the opportunity to choose a much better alternative for their future life and the existence of much (uncontrolled) passion/desire inside a human being, have clearly shown and can be used as the basic foundation of our theory. This is the reason why we believe that opportunistic behavior should also be considered and counted as a factor that can cause entrepreneurial failure.

The study has empirically shown that there is a significant relationship between the psychological construct of individuals in terms of psychoeconomic factors and opportunistic behavior and entrepreneurial failure in the context of the study. As we consider that the psychological element is a major part of preparing resilient young-nascent entrepreneurs, this study implies that strengthening and preparing the psychological aspects of young-nascent entrepreneurs should be used and viewed as a major focus for the creation of resilient young-nascent entrepreneurs. The use of a psychological approach could be one alternative way of preparing youngnascent entrepreneurs.

However, we also realize that this study has a particular limitation, and it still needs further exploration in broader contexts. As our study has only discussed one particular context (nascent entrepreneurs in one province in Indonesia), it would be worth expanding the topics of this study into a comparative study regarding the entrepreneurial failure of young-nascent entrepreneurs (between cities or regions) and to consider the causes of entrepreneurial failure in certain business branches. Another limitation is related to the single research methodology that was used in this study, which is a quantitative methodology. It would be worth expanding the methodology of this topic into a qualitative one, i.e. by using the resources of the study to fully explore the reasons for failure (psychological related, business ecosystem related and social-environmental related reasons), how the failure occurred in their business, what the impact of failure is to them, etc. This would enrich our understanding and knowledge about entrepreneurial failure and the spectrum surrounding it.

\section{CONCLUSION}

The study inferred that, simultaneously and partially, the deterministic, voluntaristic and emotive factors together with the construct of opportunistic behavior have contributed to the cause of entrepreneurial failure experienced by nascent entrepreneurs in the context of the study. We further believe and argue that the opportunism, which is reflected by the opportunistic behavior 
of individuals, should be considered both as an entrepreneurial success factor and as an entrepreneurial failure factor. We stress this and put our main attention to this issue as the originality and value of our study.

Our study implies that the creation of resilient entrepreneurs should follow entrepreneurial processes, and one of the processes could be the failure process where nascent entrepreneurs will learn from the mistakes they have made. Thus, government intervention to strengthen entrepreneurial personality and to focus on the psychological aspects regarding nascent entrepreneurs would be a sensible and reasonable policy alternative to be chosen. This can be undertaken by arranging capacity building schemes and programs for nascent entrepreneurs in order to strengthen their psychological aspects that are related to motives, maturity, logical consideration to choose alternatives, decision- making processes, dealing with social pressures, etc. Other capacity-building schemes can be related to the improvement of business knowledge where nascent entrepreneurs can learn to manage their business in more effective and efficient ways.

We also view and consider that it is worth relating this study in entrepreneurial failure to the study of entrepreneurial resilience and serial entrepreneurship. We believe that those three particular fields, with the mediation effect of the learning process, are interrelated to each other - and this could be one of the research directions related to this topic.

\section{References}

Andrunik, A.A., \& Svetlakov, A.G. (2013). Overcoming opportunistic behavior of personnel in modern companies. World Applied Sciences Journal, 22(1), 57-62. https://doi.org/10.5829/idosi.wasj.2013.22.01.13313

American Psychological Association (APA). (2010). The road to resilience: Resilience factors and strategies. Retrieved from http://www.apa.org/ helpcenter/road-resilience.aspx.12

Arasti, Z. (2011). An empirical study on the causes of business failure in Iranian context. African Journal of Business Management, 5(17), 74887498. https://doi.org/10.5897/AJBM11.402

Artinger, S., \& Powell, T. C. (2015). Entrepreneurial failure: Statistical and psychological explanations. Strategic Management Journal, 37(6), 10471064. https://doi.org/10.1002/smj.2378

Bratnicka-Myśliwiec, K., Wronka-Pośpiech, M., \& Ingram, T. (2019). Does socioemotional wealth matter for competitive advantage? A case of Polish family businesses. Journal of Entrepreneurship, Management and Innovation, 15(1), 123-146. https://doi.org/10.7341/20191515

Cardon, M. S., Stevens, C. E., \& Potter, D. R. (2011). Misfortunes or mistakes? Cultural sense making of entrepreneurial failure. Journal of Business Venturing, 26(1), 79-92. https://doi.org/10.1016/j.jbusvent.2009.06.004 
Chang, W., Liu, W.G.H., \& Chiang, S. (2014). A study of the relationship between entrepreneurship courses and opportunity identification: An empirical survey. Asia Pacific Management Review, 19(1), 1-24. http:// dx.doi.org/10.6126\%2fAPMR.2014.19.1.01

Cordes, C., Richerson, P., McElreath, R., \& Strimling, P. (2010). How does opportunistic behaviour influence firm size? An evolutionary approach to organizational behaviour. Journal of Institutional Economics, 7(1), 1-21. https://doi.org/10.1017/S1744137410000123

Devece, C., Peris-Ortiz, M., \& Rueda-Armengot, C. (2016). Entrepreneurship during economic crisis: Success factors and paths on failure. Journal of Business Research, 69(11), 5366-5370. https://doi.org/10.1016/j. jbusres.2016.04.139

Fatoki, O. (2014). The entrepreneurial intention of undergraduate students in South Africa: The influences of entrepreneurship education and previous work experience. Mediterranean Journal of Social Sciences, 5(7), 294299. http://dx.doi.org/10.5901/mjss.2014.v5n7p294

Hammer, M.H.M. (2012). How business management benefit from entrepreneurship. Paper presented at the 10th Conference of Management, Enterprise and Benchmarking, Budapest, Hungary. Retrieved from http://www.kgk.uni-obuda.hu/sites/default/files/12_ Matthijs\%20Hammer.pdf

Hammer, M.H.M., \& Khelil, N. (2014). Exploring the different patterns of entrepreneurial exit. The causes and consequences. Proceedings of the 59th ICSB World Conference on Entrepreneurship, Dublin, Ireland. Retrieved from https://pdfs.semanticscholar.org/4980/ d14545dba7a3adf7f8fdb8bb2acabb0c0ef3.pdf

Herath, H.M.T.S. (2014). Conceptualizing the role of opportunity recognition in entrepreneurial career success. International Journal of Scientific Research and Innovative Technology, 1(3), 73-82.

Hofstede, G. (2018). National culture of Indonesia. Retrieved from http:// geert-hofstede.com/indonesia.html

Jenkins, A.S., Wiklund, J., \& Brundin, E. (2014). Individual responses to firm failure: Appraisals, grief, and the influence of prior failure experience. Journal of Business Venturing, 29(1), 17-33. https://doi.org/10.1016/j. jbusvent.2012.10.006

Khelil, N. (2012). What are we talking about when we talk about entrepreneurial failure? RENT XXVI - Research in Entrepreneurship and Small Business, Lyon, France.

Khelil, N. (2016). The many faces of entrepreneurial failure: Insights from an empirical taxonomy. Journal of Business Venturing, 31(1), 72-94. https:// doi.org/10.1016/j.jbusvent.2015.08.001

Lafontaine, F., \& Shaw, K. (2014). Serial entrepreneurship: Learning by doing? Journal of Labour Economics, 34(S2), S217-S254. https://doi. org $/ 10.1086 / 683820$ 
Liang, C-T., \& Liang, C. (2015). Interaction of psychological factors in shaping entrepreneurial intention among computer and electrical engineering students. Journal of Entrepreneurship, Management and Innovation, 11(2), 5-29. https://doi.org/10.7341/20151121

Mangundjaya, W.L.H. (2010). Is there cultural change in the national cultures of Indonesia? Proceeding International Conference on Association of Cross Cultural Psychology (IACCP), Melbourne, Australia. Retrieved from https://scholarworks. gvsu.edu/cgi/viewcontent.cgi?article=1032\&context=iaccp_papers

Mantere, S., Aula, P., Schildt, H., \& Vaara, E. (2013). Narrative attributions of entrepreneurial failure. Journal of Business Venturing, 28(4), 459-473. https://doi.org/10.1016/j.jbusvent.2012.12.001

Mellahi, K., \& Sminia, H. (2009). Frontiers of strategic management research. International Journal of Management Reviews, 11(1), 1-7. https://doi. org/10.1111/j.1468-2370.2008.00248.x

Mellahi, K., \& Wilkinson, A. (2010). Managing and coping with organizational failure: Introduction to the special issue. Group and Organization Management, 35(5), 531-541. https://doi. org/10.1177\%2F1059601110383404

Rahman, H., \& Day, J. (2014). Involving the entrepreneurial role model: A possible development for entrepreneurship education. Journal of Entrepreneurship Education 17(2), 163-171.

Singh, S., Corner, P.D., \& Pavlovich, K. (2015). Failed, not finished: A narrative approach to understanding venture failure stigmatization. Journal of Business Venturing, 30(1), 150-166. http://dx.doi.org/10.1016/j. jbusvent.2014.07.005

Smida, A., \& Khelil, N. (2010). Repenser l'échec entrepreneurial des petites entreprises émergentes. Proposition d'une typologie s'appuyant sur une approche intégrative. Revue Internationale P.M.E.: économie et gestion de la petite et moyenne entreprise, 23(2), 65-106. https://doi. org/10.7202/1005762ar

Talas, E., Celik, A.K., \& Oral, I.O. (2013). The influence of demographic factors on entrepreneurial intention among undergraduate students as a career choice: The case of a Turkish university. American International Journal of Contemporary Research, 3(12), 22-31.

Tikkamäki, K., Heikkilä, P., \& Ainasoja, M. (2016). Positive stress and reflective practice among entrepreneurs. Journal of Entrepreneurship, Management and Innovation, 12(1), 7-34. https://doi.org/10.7341/20161212

Ucbasaran, D., Westhead, P., Wright, M., \& Flores, M. (2010). The nature of entrepreneurial experience, business failure and comparative optimism. Journal of Business Venturing, 25(6), 541-555. https://doi.org/10.1016/j. jbusvent.2009.04.001

Unsal, H.I., \& Taylor, J.E. (2011). An empirical investigation of opportunistic behaviour in project networks and its impact on market efficiency. Engineering Project Organization Journal, 1(2), 95-106. https://doi.org/1 $0.1080 / 21573727.2011 .569931$ 
van Gelder, J.L., Vries, R.E., Frese, M., \& Goutbeek, J.P. (2007). Differences in psychological strategies of failed and operational business owners in the Fiji Islands. Journal of Small Business Management, 45(3), 388-400. https://doi.org/10.1111/j.1540-627X.2007.00219.x

Wadhwa, V., Aggarwal, R., Holly, H., \& Salkever, A. (2009). Anatomy of an entrepreneur: Family background and motivation. The Ewing Marion Kauffman Foundation Research Report, July 2009. https://dx.doi. org/10.2139/ssrn.1431263

Wasdani, K.P., \& Mathew, M. (2014). Potential for opportunity recognition: Differentiating entrepreneurs. International Journal of Entrepreneurship and Small Business, 23(3), 336-362. https://doi.org/10.1186/22517316-2-7

Wennberg, K., \& DeTienne, D.R. (2014). What do we really mean when we talk about 'exit'? A critical review of research on entrepreneurial exit. International Small Business Journal, 32(1), 4-16. https://doi. org/10.1177/0266242613517126

Wennberg, K., Wiklund, J., DeTienne, D. R., \& Cardon, M. S. (2010). Reconceptualising entrepreneurial exit, divergent exit routes and their drivers. Journal of Business Venturing, 25(4), 361-375. https://doi. org/10.1016/j.jbusvent.2009.01.001

Yakovleva, E., Grigoryeva, N., \& Grigoryeva, O. (2016). Opportunistic behaviour as behaviour manipulations. American Journal of Applied Sciences, 13(9), 996-1005. http://doi.org/10.3844/ajassp.2016.996.1005

Yamakawa, Y., \& Cardon, M. S. (2015). Causal ascriptions and perceived learning from entrepreneurial failure. Small Business Economics, 44(4), 797-820. https://doi.org/10.1007/s11187-014-9623-z

Yaqub, M. Z. (2009). Antecedents, consequences and control of opportunistic behaviour in strategic networks. Journal of Business \& Economics Research, 7(2), 15-31.

\begin{abstract}
Abstrakt
Artykuł omawia wewnętrzne okoliczności jednostek jako czynniki, które moga powodować niepowodzenie przedsiębiorczości, na które składajq się zjawiska psychoekonomiczne i zachowania oportunistyczne. Jest to badanie ilościowe i opiera się na analizie relacyjnej, która wiq̨że istniejqce argumenty dotyczq̨ce czynników psychoekonomicznych z niepowodzeniem przedsiębiorczości. Badanie dodatkowo dodaje i analizuje konstrukcję zachowań oportunistycznych jako kolejny możliwy czynnik, który może powodować porażkę przedsiębiorczości. Próbq badania jest 1541 młodych przedsiębiorców z prowincji West Sumatra w Indonezji, którzy doświadczyli niepowodzeń w swoich wcześniejszych firmach. Analizę przeprowadzono przy użyciu analizy regresji wielokrotnej i częściowej, w której użyto protokołu statystycznego. Stwierdzono, że czynniki psychoekonomiczne wraz z oportunistycznymi zachowaniami jednostek w mniejszym lub $w$ większym stopniu spowodowały przedsiębiorczq porażkę w kontekście badania. Badanie sugeruje również, że zachowania oportunistycz-
\end{abstract}


ne mogq być nie tylko postrzegane jako źródło sukcesu przedsiębiorczości, ale także przyczyniajq się do niepowodzenia przedsiębiorczości. To odkrycie wyraźnie pokazuje oryginalność i wartość tego badania, ponieważ dowodzi, że zachowania oportunistyczne można również postrzegać jako czynnik - oprócz innych istniejqcych czynników psychoekonomicznych (deterministycznych, dobrowolnych i emocjonalnych) - które moga powodować porażkę przedsiębiorczości. Badanie sugeruje, że wzmocnienie osobowości przedsiębiorczej, cech i aspektów psychologicznych powinno być celem rzqdu indonezyjskiego w promowaniu i rozwijaniu młodych przedsiębiorców. Aspekty psychologiczne mogq odnosić się do wysiłków zmierzajqcych do wzmocnienia motywów, dojrzałości, racjonalnych procesów decyzyjnych oraz sposobów radzenia sobie z presjq społecznq, środowiskowq i biznesowq.

Słowa kluczowe:deterministyczne, dobrowolne, emocjonalne czynniki, niepowodzenia przedsiębiorcze, czynniki psychoekonomiczne, zachowania oportunistyczne

\section{Biographical notes}

Hafiz Rahman is an assistant professor at the Department of Management, Faculty of Economics, Universitas Andalas in Padang, West Sumatra - Indonesia, with scientific specialties in entrepreneurship, in particular entrepreneurial psychology and personality, and small-medium scale enterprises/SMEs, as well as the intersection between knowledge-learninginnovation in organization. His institution currently assigns him as a full faculty member in the study concentration of entrepreneurship. He wrote articles and papers in the field of entrepreneurship education and learning, culture and its linkage to entrepreneurship, ethnic and minority entrepreneurship, knowledge sharing and knowledge inertia in SMEs, individual learning in SMEs and entrepreneurial failure.

Eri Besra is an assistant professor at the Department of Management, Faculty of Economics, Universitas Andalas in Padang, West Sumatra - Indonesia. She has a specialization in marketing, with a strong background in retail marketing. She wrote papers majoring in the field of retail marketing of SMEs and entrepreneurial failure.

Nurhayati is a senior lecturer in the Department of Business Administration, Management, Politeknik Negeri Padang in Padang, West Sumatra - Indonesia. She has a specialization in business administration, with a strong background in management of enterprises. She wrote papers majoring in the field of management of SMEs and entrepreneurial failure. 


\section{Conflicts of interest}

The authors declare no conflict of interest.

\section{Citation (APA Style)}

Rahman, H., Besra, E., \& Nurhayati. (2020). Explicating failure among nascent entrepreneurs in West Sumatra: The nexus of psycho-economic factors and opportunistic behavior. Journal of Entrepreneurship, Management and Inovation, 16(2), 37-66. https://doi.org/10.7341/20201622 